УДК 94(477«1950/1960»:[684.4:070.487]

DOI: $10.24919 / 2519-058 \times .6 .123767$

Альона ЯКУБЕЦЬ, orcid.org/0000-0003-1277-1921 старший науковий співробітник відділу історії України ХХ століття Національного музею історії України (Україна, Киї) тиseum_kyiv@ukr.net

\title{
ВИРОБНИЦТВО ПОБУТОВИХ МЕБЛІВ В УРСР У 1950 - 1960-х роках: ПРОБЛЕМА ЯКОСТІ (ЗА ПУБЛІКАЦІЯМИ ЖУРНАЛУ «ПЕРЕЦЬ»)
}

\begin{abstract}
У статті розглядається проблема забезпечення побутовими меблями жителів України у середині 1950 - середині 1960-х рр. на тлі розгорнутого у той час масового будівництва малогабаритного житла (т. зв. «хрущівок»). Зроблено иее на основі публікацій журналу «Перещь», який, в силу його жанрової спеииффіки, визначено важливим джерелом з історії повсякдення України другої половини XX ст. Детально висвітлено і проаналізовано два ключові моменти: незадоволеність попиту на гостродефіцитні меблі та тотально низьку якість (брак) продукції меблевих підприємств УРСР (з переліком иих виробництв). Зроблено висновок про системність ичих явищ, які були пов'язані з хибністю радянської соціально-економічної системи загалом, а також - про ијінність журналу «Перецьь» як джерела з вивчення історії повсякдення України за радянських часів.
\end{abstract}

Ключові слова: історія повсякдення, УРСР, журнал «Перещъ», меблі.

Aliona YAKUBETS,

Senior Researcher, Department of History of Ukraine of the $20^{\text {th }}$ century, National Museum of History of Ukraine (Ukraine, Kyiv) museum_kyiv@ukr.net

\section{MANUFACTURE OF HOUSEHOLD FURNITURE IN SOVIET UKRAINE IN 1950 - 1960': PROBLEM OF QUALITY (ACCORDING TO THE PERETS MAGAZINE)}

During 1950s - 1960s in connection with beginning of mass housing building in the USSR, conceptually - on a state level - approach changed to furnitures as such: there was a transition from primitive of their productionto industrial, standardised, conveyer type. This was due to the new course of the Soviet leadership, which after the death of J. Stalin (1953) began to somewhat shift the economic priorities and emphases from the militaryindustrial complex for the production of consumer goods, the so-called the Group B industry. However theme of production of furniture on territory of Ukraine so far did not become the separate article of research of domestic historians. One of the reasons for this is the lack of the elaboration of appropriate sources, one of the components of which is the publications in the satirical and humorous magazine the Perets, which, according to its genre specificity, has focused much attention on the domestic aspects of the existence of the inhabitants of Soviet Ukraine. The main thesis of the article is a demonstration on the example of the quality of domestic furniture in the Ukrainian SSR of the value of the Perets magazine as a source of the history of the everyday life of Ukraine in the Soviet period.

In particular, it was determined that during the mid-1950s - mid-1960s, furniture problems on the pages of the Perets magazine in one form or another were interpreted almost 80 times. The main directions of these publications are excess of demand over supply for domestic furniture (deficit), as well as the extremely low quality (defect) of products available for sale.

The last problem was mass and systemic: on the pages of Perets magazine during 1954 - 1965 in the negative context, the products of 47 furniture enterprises (their complete list is given in the original article) from the nearly 200 available at that time in the Ukrainian SSR was mentioned. These are, first of all, wardrobes, bedrooms (beds and sofas), chairs, kitchen tables and writing tables, kitchen cupboards.

However, despite the apparent systematic nature of the phenomenon, none of authors of the Perets magazine did not make an attempt analyse the similar situation. Everything was limited only to the statement of facts filed in 
a satirical-humorous clue. At the same time, the deepening in the cause-and-effect relation would inevitably lead to the conclusion that the whole Soviet system as such and, in particular, its economic component, were fallaciousness.

Thus, using inductive and quantitative methodologies, on the example of a local topic (the quality of domestic furniture in Soviet Ukraine), it was possible to prove the thesis that the satirical-humorous the Perets magazine is an important public source for studying the history of everyday life. Moreover - in any of its segments.

Key words: history of everyday life, the Ukrainian Soviet Socialist Republic, the Perets magazine, furniture.

Алена ЯКУБЕЦ,

стариий научньй сотрудник отдела истории Украинь ХХ века

Национального музея истории Украинь (Украина, Киев) тиseum_kyiv@ukr.net

\section{ПРОИЗВОДСТВО БЫТОВОЙ МЕБЕЛИ В УССР В 1950 - 1960-х ГОДАХ: ПРОБЛЕМА КАЧЕСТВА (ПО ПУБЛИКАЦИЯМ ЖУРНАЛА «ПЕРЕЦ»)}

В статье рассматривается проблема обеспечения бытовой мебелью жителей Украины в середине 1950 - середине 1960-х гг. на фоне развернутого в то время массового строительства малогабаритного жилья (т. н. «хрущевок»). Сделано это на основе публикаций журнала «Переиџ», который, в силу его жанровой специфики, определен важным источником по истории повседневности Украины второй половины $X X$ в. Подробно освещены и проанализированы два ключевых момента: неудовлетворенность спроса на остродефицитную мебель и тотально низкое качество (брак) продукиии мебельных предприятий УССР (с перечнем этих производств). Сделан вывод о системности данных явлений, которые были связаны с порочностью советской социально-экономической системы в иелом, а также - о иченности журнала "Переиџ» как источника по изучению истории повседневности Украины советского периода.

Ключевые слова: история повседневности, УССР, журнал «Переи», мебель.

Постановка проблеми. Меблі - базова та невід'ємна частина будь-якого інтер'єру, а відтак - одна з основоположних складових побуту людини. Звідси - неможливість у процесі вивчення історії повсякдення оминути меблеву тематику, що, власне, й зумовлює іï актуальність. Це стосується як вивчення побуту загалом, так i, рівною мірою, життя українців за часів СРСР. Особливо ж - періоду 1950 - 1960-х рр., коли, у зв’язку з початком масового житлового будівництва, концептуально - на державному рівні - змінився підхід до меблів як таких: відбувся перехід від штучного, напівкустарного (а нерідко - відверто кустарного) їх виробництва (наприклад, у 1935 р. із 169 зареєстрованих в УРСР меблевих виробництв 126 належали до категорії дрібних) (Народне господарство, 1935: 48) - до промислового, стандартизованого, конвеєрного, побудованого на принципі взаємозамінності деталей та вузлів (Беловинский, 2015: 381). Якщо у другій половині 1940-х рр. нормою обстановки житлових помешкань було ліжко та кілька дерев'яних ящиків у ролі стола та стільців (Прохоренко, 2010: 192), то у середині 1950-х вже з'являються такі поняття, як «розбірні меблі» та «меблевий гарнітур для малогабаритної квартири» (Безбородько, 1958; Мебельная промышленность, 1954: 596; Мебельный гарнитур, 1954).

Усе це пов'язувалося 3 новим курсом радянського керівництва, яке після смерті Йосипа Сталіна (1953) почало, нехай невпевнено, але все-таки пробувати дещо змістити економічні пріоритети й акценти з військово-промислового комплексу на виробництво предметів споживання - т. зв. «промисловість групи Б», до якої належало і виготовлення меблів (Янковська, 2015: 221). Не цурався на цю тему говорити і сам новий радянський лідер - Микита Хрущов, котрий, будучи вірним принципу «ручного управління», особисто переймався не лише стратегічними питаннями меблевої промисловості, а й дизайном стільців, шаф та ліжок (Василенко, 1963).

Аналіз досліджень. Проблема полягає у тому, що меблі в історичному контексті поки що не стали окремим предметом дослідження вітчизняних науковців. Причину тут можна вбачати не лише у «дрібності» теми (все-таки, на широкий загал - не базова галузь економіки, і навіть у структурі тієї ж «групи Б» на початок 1980-х років виробництво меблів в СРСР становило лише 
3,1%) (Народное хозяйство, 1987: 129) та відносній «молодості» вітчизняних студій з історії повсякдення (далеко не всі ще ії напрями охоплені увагою науковців), а й у відсутності розробки відповідної джерельної бази, одним із складових елементів якої є публікації у тогочасній пресі, зокрема - у сатирично-гумористичному журналі «Перець», який, відповідно до своєї жанрової специфіки, значною мірою концентрував увагу саме на побутових аспектах буття жителів радянської України.

Мета статті. На прикладі висвітлення питання якості побутових меблів у радянській Україні продемонструвати цінність журналу «Перець» як джерела з вітчизняної історії повсякдення.

Виклад основного матеріалу. Аналіз підшивок «Перця» за 1954 - 1965 рр. (всього - 288 номерів; журнал виходив двічі на місяць) показав, що меблева проблематика займала на його сторінках одне з чільних місць. Загалом виявлено 79 відповідних публікацій (в середньому - одна на три-чотири номери), поданих у вигляді фейлетонів, заміток, листів читачів та карикатур. При цьому спостерігається показова прогресія: 1954 р. - 3 публікації, 1955-й - 2, 1956-й - 3, 1957-й 3, 1958-й - 6, 1959-й - 6, 1960-й - 10, 1961-й - 2, 1962-й - 6, 1963-й - 23, 1964-й - 8, 1965-й - 7. Очевидний «провал» у 1961 - 1962 рр. можна пояснити тим, що на цей проміжок часу припадає закінчення будівництва першої серії «хрущівок», яке у Києві (а відтак - в Україні) було розпочате у 1956 р., і старт нової хвилі масового житлового будівництва, що тривала до середини 1970-х р. (Киев, 1985: 35, 96, 111, 309-310, 429-430, 458, 472, 537, 578, 707; Пономаренко, Різник, 2003: $4,15-16,18,34,45-46,51,60,63,66,76)$. Редакція «Перця», вочевидь, очікувала на відповідні ідеолого-методологічні вказівки від Центрального Комітету Компартії України, якому підпорядковувалася.

Перше очевидне свідчення нових «меблевих віянь» з'явилося у першому номері «Перця» за 1958 р. у вигляді фейлетону Григорія Безбородька «Погоня за невидимками», де йшлося про гостру потребу у сучасних компактних та комбінованих меблях для нових малометражних квартир. Зразки такої продукції були представлені на Республіканській виставці меблів, однак до масового промислового виробництва виставкових зразків, справа, схоже, так і не дійшла (Безбородько, 1958).

Проблема невідповідності «виставкової» та «масової» меблевої продукції залишалася актуальною і через два роки (Каплан, 1960), і через чотири (Лович, 1962). До неї додавалося також питання консерватизму у дизайні гарнітурів та окремих видів продукції (Глазовий та ін., 1960; Здоровенькі були, 1960; Зелінський, 1959b).

Та левова частка перчанських публікацій стосовно меблів у 1950 - 1960-х рр. - це тема бракованої продукції. Проблема мала масовий та системний характер - впритул до того, що вважалося за норму разом із покупкою нових меблів відразу ж запрошувати майстра, котрий мав їх «обтесати та підігнати» (Бойко, 1957; Чабанівський, 1958).

Оскільки виробництво меблів організаційно належало до т. зв. місцевої промисловості, у торговельній мережі України була присутня продукція переважно вітчизняного виробництва. Причому географія меблевих підприємств, які критикувалися на сторінках «Перця», охоплювала всі регіони УРСР. Зокрема, браковані побутові меблі випускали:

на Буковині - Чернівецька меблева фабрика (Дошка, 1963a; Чернівецька меблева фабрика, 1962);

на Вінниччині - Бершадська меблева фабрика (Прицкер, 1963), Вінницький деревообробний комбінат (Дошка, 1963b), Тростянецький деревообробний комбінат (Будьте обережні, 1956; Збилися $з$ ніжок, 1961);

на Дніпропетровщині - Верхньодніпровський райпромкомбінат (Комбінований брак, 1963), Дніпропетровський завод «Червоний металіст» (Молякевич, 1965; У дніпропетровських бракоробів, 1963), Павлоградський міськпромкомбінат (Комбінований брак, 1963);

на Житомирщині - Бердичівська меблева фабрика (Дошка, 1963d), Житомирська артіль «За якість» (Не вір, 1956), Житомирська меблева фабрика (Молякевич, 1965; Наконечний, 1964), Коростенська артіль «Четверта п’ятирічка» (Добрянський, 1958), Коростишівська меблева фабрика (Онищук, 1963), Малинська фабрика гнутих меблів (Ведмідь-консультант, 1963; Збилися з ніжок, 1959), Чоповицька фабрика гнутих меблів (Дошка, 1963c); 
на Закарпатті - Виноградівська меблева фабрика (Властивість, 1963), Свалявська меблева фабрика (Свалявська новинка, 1965), Тячівський райпромкомбінат (Не останні, 1963), Ужгородський фанерно-меблевий комбінат (Заруба, 1957; Звідки дрівця, 1965);

на Запоріжжі - Запорізька меблева фабрика (Фантастика, 1963);

на Івано-Франківщині - Болехівський райпромкомбінат (Дійшли до ручки, 1964), Городенківська артіль ім. XIX партз'їзду (День і ніч, 1959), Рожнятівський лісокомбінат (Декоративні шафи, 1964);

у Києві - Дарницький фанерний комбінат (Чому приймач плакав, 1960), Київський ліжковий завод (Сон і сновидіння, 1963; У київських бракоробів, 1963);

на Київщині - Васильківська артіль «Деревообробник» (І не спиться, 1955), Фастівський меблевий комбінат (А де портрет, 1963; Плахотник, Бондаренко, 1965);

на Кіровоградщині - Кіровоградська меблева фабрика (Соловйов, 1960), Новоукраїнський меблевий комбінат «Зірка» (Харченко, Діденко, 1963), Олександрійська меблева фабрика (Гливенко, 1963; Харченко, Діденко, 1963);

у Криму - Сімферопольський меблевий комбінат (Покороблені коробки, 1960);

на Луганщині - Луганська ліжкова фабрика (Наступ, 1965);

на Львівщині - Львівська меблева фабрика № 5 (Дорога, 1957), Львівська меблева фабрика «Карпати» (Своя «індивідуальність», 1963);

на Миколаївщині - Миколаївський міськпромкомбінат (Історія хвороби, 1962), Первомайська меблева фабрика (Для «кімнати жахів», 1962);

на Одещині - Балтський меблевий комбінат (Кому віддати, 1963), Котовська меблева фабрика (Кому віддати, 1963), Одеська меблева фабрика (Одеський фанерно-меблевий комбінат) (Дрова, 1960; Кому віддати, 1963; Ошукані ювіляри, 1965);

на Полтавщині - Лубенський фанерно-меблевий комбінат (Лубенська меблева фабрика) (Високоякісні дрова, 1963; Недарма сказано, 1956), Пирятинська меблева фабрика (Перчанський вертольот, 1960);

на Сумщині - Роменська меблева фабрика (Буфет, 1958), Сумський міськпромкомбінат (Буда, 1963);

на Харківщині - Харківський меблевий комбінат (Буфет, 1954; На ноги, 1955);

на Хмельниччині - Хмельницька артіль ім. Кірова (Робиться так, 1959);

на Черкащині - Чигиринська артіль ім. Хмельницького (Паламар, 1960; Потішні меблі, 1960), Шполянська меблева фабрика (Одна нога, 1964; Свіжий брак, 1959; Унікальна знахідка, 1958);

на Чернігівщині - Прилуцький меблевий комбінат (Брак, 1956; Перчанський вертольот, 1960).

Що ж стосується номенклатури меблевої продукції, низька якість якої знайшла своє відображення на сторінках «Перця», то вона складається всього із п'яти позицій:

шафи для одягу (перекошеність дверей та всієї конструкції, невідрегульованість завіс, низька якість лакофарбового покриття та базових деревостружкових матеріалів, відсутність необхідних комплектуючих, відсутність дзеркал для відповідних моделей, або ж невідповідність розмірів дзеркал нішам у шафах, непридатність виробів для експлуатації відразу ж після покупки, застарілий дизайн, непривабливий зовнішній вигляд загалом) - 35 \% публікацій (А де портрет, 1963; Брак, 1956; Буда, 1963; Властивість, 1963; Декоративні шафи, 1964; День і ніч, 1959; Дійшли до ручки, 1964; Для «кімнати жахів», 1962; Дошка, 1963а; Заруба, 1957; Звідки дрівця, 1965; Кому віддати, 1963; Михайлюк, 1954; Молякевич, 1965; Навіщо, 1961; Онищук, 1963; Паламар, 1960; Перчанський вертольот, 1960; Покороблені коробки, 1960; Потішні меблі, 1960; Робиться так, 1959; Своя «індивідуальність», 1963; Соловйов, 1960; Фантастика, 1963);

спальні меблі - ліжка та дивани (низька якість деревини, наповнювачів м'якої частини, пружин та лакофарбового покриття, непривабливий зовнішній вигляд) - 21 \% (Гливенко, 1963; Дошка, 1963d; I не спиться, 1955; Історія хвороби, 1962; Комбінований брак, 1963; Кому віддати, 1963; Молякевич, 1965; Наступ, 1965; Не останні, 1963; Свалявська новинка, 1965; Сон і снови- 
діння, 1963; У дніпропетровських бракоробів, 1963; У київських бракоробів, 1963; Фантастика, 1963; Харченко, Діденко, 1963);

стільці (хисткість конструкцій, підламування ніжок, низька якість матеріалів та лакофарбового покриття, непривабливий зовнішній вигляд) - 20 \% (Будьте обережні, 1956; Ведмідь-консультант, 1963; Високоякісні дрова, 1963; Дошка, 1963a; Дошка, 1963с; Дрова, 1960; Загублено честь, 1962; Збилися з ніжок, 1959; Збилися з ніжок, 1961; Комбінований брак, 1963; Наконечний, 1964; Одна нога, 1964; Толкачов, 1954; Чернівецька меблева фабрика, 1962);

столи кухонні та письмові (хисткість та незбалансованість конструкцій, проблеми із шухлядами, необроблені поверхні, низька якість матеріалів та лакофарбового покриття, непривабливий зовнішній вигляд) - 15 \% (Добрянський, 1958; Дошка, 1963а; Комбінований брак, 1963; Кому віддати, 1963; На ноги, 1955; Не вір, 1956; Недарма сказано, 1956; Свіжий брак, 1959; Унікальна знахідка, 1958; Фантастика, 1963; Чому приймач плакав, 1960);

буфети кухонні (перекошеність конструкцій, невідрегульованість вузлів, випадіння стекол, відсутність комплектуючих, непривабливий зовнішній вигляд) - 9 \% (Буфет, 1954; Буфет, 1958; Ведмідський, 1962; Кому віддати, 1963; Прицкер, 1963; Фантастика, 1963).

Усього ж на сторінках «Перця» впродовж 1954 - 1965 рр. у негативному контексті згадувалася продукція 47 меблевих підприємств (із майже 200, наявних на той час в УРСР) (Гонтар, 1981: 424), розташованих на території 21 області України (на кінець 1954 р. в УРСР остаточно сформувалася система адміністративно-територіального поділу - 25 областей та 2 міста центрального підпорядкування, яка, в своїй основі, діє дотепер). При цьому деякі із них, як от Малинська фабрика гнутих меблів, Одеський фанерно-меблевий комбінат, Шполянська меблева фабрика - фігурували у публікаціях неодноразово.

Усе це сукупно свідчить про очевидну системність явища. Проте не зафіксовано жодного хоча б натяку на спробу проаналізувати подібний стан справ - все обмежувалося лише констатацією фактів, поданих у сатирично-гумористичному ключі, що має цілком зрозуміле пояснення. Заглиблення у причино-наслідкові зв'язки неминуче привело б будь-яку мислячу людину (а серед співробітників «Перця», треба гадати, таких вистачало) до висновку про хибність всієї радянської системи як такої i, зокрема - iї економічної складової, в основу якої були покладені кількісні, а не якісні показники, що, зі свого боку, означало відсутність зацікавленості виробника у ретельному ставленні до виготовлення продукції - він не мав для цього жодного стимулу, насамперед - матеріального.

Висновки. Вся вищевикладена інформація (насамперед їі максимально деталізована та конкретизована складова) дає підстави для висновку, що журнал «Перець» може слугувати важливим інформативним джерелом під час досліджень побуту жителів України за радянських часів. Причому, це стосується не лише меблів - на сторінках журналу присутня велика кількість конкретної інформації щодо чи не всіх аспектів історії повсякдення. А тому це видання потребує подальшого ретельного вивчення й опрацювання.

\section{СПИСОК ВИКОРИСТАНИХ ДЖЕРЕЛ І ЛІТЕРАТУРИ}

А де портрет, 1963 - А де портрет? // Перець. 1963. № 17. С. 2.

Александрович, 1958 - Александрович І. Це ви довели до того.... карикатура // Перець. 1958. № 10. С. 3. Александрович, 1959 - Александрович І. Аби вал був: карикатура // Перець. 1959. № 17. С. 1.

Безбородько, 1958 - Безбородько Г. Погоня за невидимками // Перець. 1958. № 1. С. 4.

Беловинский, 2015 - Беловинский Л. В. Энциклопедический словарь истории советской повседневной жизни. Москва, 2015. 776 с.

Бе-Ша, 1964 - Бе-Ша. Ледар критикує...: карикатура // Перець. 1964. № 17. С. 4.

Бойко, 1957 - Бойко Л. Слідами браку: карикатура // Перець. 1957. № 11. С. 4.

Брак, 1956 - Брак 1-го сорту // Перець. 1956. № 16. С. 8.

Буда, 1963 - Буда $з$ артикулом // Перець. 1963. № 18. С. 3.

Будьте обережні, 1956 - Будьте обережні! // Перець. 1956. № 9. С. 12.

Буфет, 1954 - Буфет з секретами // Перець. 1954. № 22. С. 10.

Буфет, 1958 - Буфет дуже оригінальної конструкції... // Перець. 1958. № 12. С. 10.

Василенко, 1963 - Василенко А. А ось і автори цього ліжка: карикатура // Перець. 1963. № 1. С. 7. 
Ведмідський, 1962 - Ведмідський А. Давай зробимо так... // Перець. 1962. № 24. С. 5.

Ведмідь-консультант, 1963 - Ведмідь-консультант // Перець. 1963. № 13. С. 2.

Високоякісні дрова, 1963 - Високоякісні дрова... // Перець. 1963. № 12. С. 3.

Властивість, 1963 - Властивість поштових голубів... // Перець. 1963. № 7. С. 3.

Глазовий та ін., 1960 - Глазовий П., Золотаревський І., Білецький М. Як я обставився // Перець. 1960. № 22. C. 6-7.

Гливенко, 1963 - Гливенко В. Ведмежа послуга: карикатура // Перець. 1963. № 21. С. 3.

Гонтар, 1981 - Гонтар М. А. Меблева промисловість // Українська Радянська Енциклопедія: У 12-ти томах. Том 6. Київ, 1981. С. 423-424.

Григорчук, 1963 - Григорчук Б. Купиш - куриш! // Перець. 1963. № 23. С. 11.

Декоративні шафи, 1964 - Декоративні шафи // Перець. 1964. № 13. С. 5.

День і ніч, 1959 - День і ніч відкритих дверей... // Перець. 1959. № 21. С. 12.

Дійшли до ручки, 1964 - Дійшли до ручки // Перець. 1964. № 7. С. 3.

Для «кімнати жахів», 1962 - Для «кімнати жахів» // Перець. 1962. № 3. С. 11.

Добрянський, 1958 - Добрянський В. Любий Перче! // Перець. 1958. № 8. С. 11.

Дорога, 1957 - Дорога, малошановна... // Перець. 1957. № 1. С. 7.

Дошка, 1963а - Дошка заслужених бракоробів // Перець. 1963. № 5. С. 2.

Дошка, 1963b - Дошка заслужених бракоробів // Перець. 1963. № 13. С. 3.

Дошка, 1963c - Дошка заслужених бракоробів // Перець. 1963. № 19. С. 3.

Дошка, 1963d - Дошка заслужених бракоробів // Перець. 1963. № 21. С. 3.

Дрова, 1960 - Дрова найвищого гатунку! // Перець. 1960. № 6. С. 12.

Загублено честь, 1962 - Загублено честь фабричної марки // Перець. 1962. № 6. С. 12.

Заруба, 1957 - Заруба К. Казали ж ми тобі...: карикатура // Перець. 1957. № 3. С. 4.

Збилися з ніжок, 1959 - Збилися з ніжок // Перець. 1959. № 12. С. 10.

Збилися з ніжок, 1961 - Збилися з ніжок // Перець. 1961. №6. С. 10.

Звідки дрівця, 1965 - Звідки дрівця! // Перець. 1965. № 13. С. 5.

Здоровенькі були, 1960 - Здоровенькі були! // Перець. 1960. № 19. С. 2.

Зелінський, 1959а - Зелінський В. Ще раз про якість меблів: карикатура // Перець. 1959. № 7. С. 10.

Зелінський, 1959b - Зелінський В. Наша продукція випробувана...: карикатура // Перець. 1959. № 23. C. 4 .

I не спиться, 1955 - I не спиться, й не лежиться // Перець. 1955. № 22. С. 8.

Історія хвороби, 1962 - Історія хвороби // Перець. 1962. № 3. С. 11.

Каплан, 1960 - Каплан Л. Поглянь, який красунь стоїть...: карикатура // Перець. 1960. № 23. С. 2.

Киев, 1985 - Киев. Энциклопедический справочник / Под редакцией А. В. Кудрицкого. Киев, 1985. 794 с.

Комбінований брак, 1963 - Комбінований брак // Перець. 1963. № 14. С. 3.

Кому віддати, 1963 - Кому віддати пальму першості? // Перець. 1963. № 3. С. 3.

Лович, 1962 - Лович А. Йдеться про нас... / А. Лович // Перець. 1962. № 23. С. 6.

Мебельная промышленность, 1954 - Мебельная промышленность // Большая Советская Энциклопедия:

В 50-ти томах. Том 26. Москва, 1954. С. 596-597.

Мебельный гарнитур, 1954 - Мебельный гарнитур // Большая Советская Энциклопедия: В 50-ти томах. Том 26. Москва, 1954. С. 597.

Михайлюк, 1954 - Михайлюк М. Дорогий Перче! // Перець. 1954. № 12. С. 11.

Молякевич, 1965 - Молякевич Д. Страшна помста // Перець. 1965. № 4. С. 9.

На ноги, 1955 - На ноги! // Перець. 1955. № 7. С. 4.

Навіщо, 1961 - Навіщо шафі ніжки? // Перець. 1961. № 16. С. 10.

Наконечний, 1964 - Наконечний А. Чи не можеш ти нас проконсультувати?.. // Перець. 1964. № 20. С. 10.

Народне господарство, 1935. - Народне господарство УРСР: Статистичний довідник / За редакцією А. М. Асаткіна. Київ, 1935. 664 с.

Народное хозяйство, 1987 - Народное хозяйство СССР за 70 лет: Юбилейный статистический ежегодник. Москва, 1987. 766 с.

Наступ, 1965 - Наступ луганських ліжковиків // Перець. 1965. № 2. С. 2.

Не вір, 1956 - Не вір очам своїм // Перець. 1956. № 16. С. 8.

Не останні, 1963 - Не останні новинки... // Перець. 1963. № 17. С. 2.

Недарма сказано, 1956 - Недарма сказано...// Перець. 1956. № 13. С. 10.

Одна нога, 1964 - Одна нога - тут, друга - там // Перець. 1964. № 11. С. 3.

Онищук, 1963 - Онищук К. Намалюйте рецензію // Перець. 1963. № 9. С. 3.

Ошукані ювіляри, 1965 - Ошукані ювіляри // Перець. 1965. № 13. С. 5. 
Паламар, 1960 - Паламар Є. Купила я... // Перець. 1960. № 9. С. 8.

Перчанський вертольот, 1960 - Перчанський вертольот // Перець. 1960. № 19. С. 8.

Плахотник, Бондаренко, 1965 - Плахотник А., Бондаренко Б. Хочеш разом 3 нами поворожити?... // Перець. 1965. № 20. С. 10.

Покороблені коробки, 1960 - Покороблені коробки // Перець. 1960. № 11. С. 2.

Пономаренко, Різник, 2003 - Пономаренко Л., Різник О. Київ. Короткий топонімічний довідник. Київ, 2003. $124 \mathrm{c}$.

Потішні меблі, 1960 - Потішні меблі // Перець. 1960. № 10. С. 11.

Прицкер, 1963 - Прицкер М. Умови бракоробів // Перець. 1963. № 21. С. 3.

Прохоренко, 2010 - Прохоренко О. Науково-педагогічна інтелігенція як соціально-професійний прошарок в 1945 - 1955 рр. // Повоєнна Україна: нариси соціальної історії (друга половина 1940-х - середина 1950-х рр.): У 2-х книгах, 3-х частинах. Книга 1, частини 1-2 / Відповідальний редактор В. М. Даниленко. Київ, 2010. С. 177-208.

Робиться так, 1959 - Робиться так... // Перець. 1959. № 10. С. 10.

Свалявська новинка, 1965 - Свалявська новинка // Перець. 1965. № 17. С. 10.

Свіжий брак, 1959 - Свіжий брак // Перець. 1959. № 10. С. 10.

Своя «індивідуальність», 1963 - Своя «індивідуальність» // Перець. 1963. № 12. С. 3.

Соловйов, 1960 - Соловйов Г. Колись забобонні люди ворожили... // Перець. 1960. № 12. С. 9.

Сон і сновидіння, 1963 - Сон і сновидіння // Перець. 1963. № 1. С. 2.

Толкачов, 1954 - Толкачов 3. А чому не сідати?..: карикатура // Перець. 1954. № 10. С. 7.

У дніпропетровських бракоробів, 1963 - У дніпропетровських бракоробів // Перець. 1963. № 14. С. 3.

У київських бракоробів, 1963 - У київських бракоробів // Перець. 1963. № 18. С. 3.

Унікальна знахідка, 1958 - Унікальна знахідка // Перець. 1958. № 13. С. 11.

Фантастика, 1963 - Фантастика на стендах // Перець. 1963. № 6. С. 2.

Харченко, Діденко, 1963 - Харченко Б., Діденко К. Про дивани, кепки і паралелі // Перець. 1963. № 22. C. 3 .

Чабанівський, 1958 - Чабанівський М. Гордіїв вузол // Перець. 1958. № 11. С. 6-7.

Чернівецька меблева фабрика, 1962 - Чернівецька меблева фабрика випускає у продаж...// Перець. 1962. № 4. C. 6.

Чому приймач плакав, 1960 - Чому приймач плакав... // Перець. 1960. № 11. С. 2.

Янковська, 2015 - Янковська О. Індустріалізація житлового будівництва // Соціальні трансформації в Україні: пізній сталінізм і хрущовська доба: Колективна монографія. Київ, 2015. С. 213-231.

\section{REFERENCES}

A de portret, 1963 - A de portret? [And where is the portrait?]. Perets, 1963, Nr 17, p. 2 [in Ukrainian].

Aleksandrovych, 1958 - Aleksandrovych I. Tse vy dovely do toho...: karykatura [You have done this...: caricature]. Perets, 1958, Nr 10, p. 3 [in Ukrainian].

Aleksandrovych, 1959 - Aleksandrovych I. Aby val buv: karykatura [If only gross output was: caricature]. Perets, 1959, Nr 17, p. 1 [in Ukrainian].

Bezborodko, 1958 - Bezborodko H. Pohonia za nevydymkamy [The pursuit of the invisible]. Perets, 1958, Nr 1, p. 4 [in Ukrainian].

Belovinskii, 2015 - Belovinskii L. V. Entsyklopedicheskii slovar istorii sovetskoi povsednevnoi zhizni [Encyclopaedic dictionary of the history of Soviet everyday life]. Moscow, 2015. 776 p. [in Russian].

Be-Sha, 1964 - Be-Sha. Ledar krytykuie.... karykatura [Sluggard criticizes...: caricature]. Perets, 1964, Nr 17, p. 4 [in Ukrainian].

Boiko, 1957 - Boiko L. Slidamy braku: karykatura [In the footsteps of the spoilage: caricature]. Perets, 1957, Nr 11, p. 4 [in Ukrainian].

Brak, 1956 - Brak 1-ho sortu [Spoilage of prime quality]. Perets, 1956, Nr 16, p. 8 [in Ukrainian].

Buda, 1963 - Buda z artykulom [Box with an article]. Perets, 1963, Nr 18, p. 3 [in Ukrainian].

Budte oberezhni, 1956 - Budte oberezhni! [Be careful!]. Perets, 1956, Nr 9, p. 12 [in Ukrainian].

Bufet, 1954 - Bufet z sekretamy [Sideboard with secrets]. Perets, 1954, Nr 22, p. 10 [in Ukrainian].

Bufet, 1958 - Bufet duzhe oryhinalnoi konstruktsii... [Sideboard with very original design...]. Perets, 1958, Nr 12, p. 10 [in Ukrainian].

Vasylenko, 1963 - Vasylenko A. A os i avtory tsoho lizhka: karykatura [And here are the authors of this bed: caricature]. Perets, 1963, Nr 1, p. 7 [in Ukrainian].

Vedmidskyi, 1962 - Vedmidskyi A. Davai zrobymo tak... [Let us do so...]. Perets, 1962, Nr 24, p. 5 [in Ukrainian]. 
Vedmid-konsultant, 1963 - Vedmid-konsultant [Bear is consultant]. Perets, 1963, Nr 13, p. 2 [in Ukrainian].

Vysokoiakisni drova, 1963 - Vysokoiakisni drova... [High-quality firewood...]. Perets, 1963, Nr 12, p. 3 [in Ukrainian].

Vlastyvist, 1963 - Vlastyvist poshtovykh holubiv... [The property of mail pigeons...]. Perets, 1963, Nr 7, p. 3 [in Ukrainian].

Hlazovyi et al., 1969 - Hlazovyi P., Zolotarevskyi I., Biletskyi M. Yak ya obstavyvsia [How I furnished one's place]. Perets, 1960, Nr 22, pp. 6-7 [in Ukrainian].

Hlyvenko, 1963 - Hlyvenko V. Vedmezha posluha: karykatura [Disservice: caricature]. Perets, 1963, Nr 21, p. 3 [in Ukrainian].

Hontar, 1981 - Hontar M. A. Mebleva promyslovist [Furniture industry]. Ukrayinska Radyanska Entsykldopediia: U 12-ty tomakh. Tom 6. Kyiv, 1981, pp. 423-424 [in Ukrainian].

Hryhorchuk, 1963 - Hryhorchuk B. Kupysh - kurysh! [Bought - smoked!]. Perets, 1963, Nr 23, p. 11 [in Ukrainian].

Dekoratyvni shafy, 1964 - Dekoratyvni shafy [Decorative wardrobes]. Perets, 1964, Nr 13, p. 5 [in Ukrainian].

Den i nich, 1959 - Den i nich vidkrytykh dverei... [Day and night of the open doors...]. Perets, 1959, Nr 21, p. 12 [in Ukrainian].

Diishly do ruchky, 1964 - Diishly do ruchky [Reached the door handle]. Perets, 1964, Nr 7, p. 3 [in Ukrainian].

Dlya kimnaty zhakhiv, 1962 - Dlia «kimnaty zhakhiv» [For the Room of Horrors]. Perets, 1962, Nr 3, p. 11 [in Ukrainian].

Dobrianskyi, 1958 - Dobrianskyi V. Liubyi Perche! [Dear Perets!]. Perets, 1958, Nr 8, p. 11 [in Ukrainian].

Doroha, 1957 - Doroha, maloshanovna... [Dear, not dear...]. Perets, 1957, Nr 1, p. 7 [in Ukrainian].

Doshka, 1963a - Doshka zasluzhenykh brakorobiv [Honours Board of Bunglers]. Perets, 1963, Nr 5, p. 2 [in Ukrainian].

Doshka, 1963b - Doshka zasluzhenykh brakorobiv [Honours Board of Bunglers]. Perets, 1963, Nr 13, p. 3 [in Ukrainian].

Doshka, 1963c - Doshka zasluzhenykh brakorobiv [Honours Board of Bunglers]. Perets, 1963, Nr 19, p. 3 [in Ukrainian].

Doshka, 1963c - Doshka zasluzhenykh brakorobiv [Honours Board of Bunglers]. Perets, 1963, Nr 21, p. 3 [in Ukrainian].

Drova, 1960 - Drova naivyshchoho gatunku! [High-quality firewood!]. Perets, 1960, Nr 6, p. 12 [in Ukrainian].

Zahubleno chest, 1962 - Zahubleno chest fabrychnoi marky [The honor of the trade mark is lost]. Perets, 1962, Nr 6, p. 12 [in Ukrainian].

Zaruba, 1957 - Zaruba K. Kazaly zh my tobi...: karykatura [We said to you...: caricature]. Perets, 1957, Nr 3, p. 4 [in Ukrainian].

Zbylysia z nizhok, 1959 - Zbylysia z nizhok [They ran off one's legs]. Perets, 1959, Nr 12, p. 10 [in Ukrainian].

Zbylysia z nizhok, 1961 - Zbylysia z nizhok [They ran off one's legs]. Perets, 1961, Nr 6, p. 10 [in Ukrainian].

Zvidky drivtsia, 1965 - Zvidky drivtsia? [Where did the firewood come from?]. Perets, 1965, Nr 13, p. 5 [in Ukrainian].

Zdorovenki buly, 1960 - Zdorovenki buly! [Hello!]. Perets, 1960, Nr 19, p. 2 [in Ukrainian].

Zelinskyi, 1959a - Zelinskyi V. Shche raz pro yakist mebliv: karykatura [Once again about the quality of the furniture: caricature]. Perets, 1959, Nr 7, p. 10 [in Ukrainian].

Zelinskyi, 1959b - Zelinskyi V. Nasha produktsiia vyprobuvana...: karykatura [Our products are tested...: caricature]. Perets, 1959, Nr 23, p. 4 [in Ukrainian].

I ne spytsia, 1955 - I ne spytsia, i ne lezhytsia [And will not sleep, and not will lie down]. Perets, 1955, Nr 22, p. 8 [in Ukrainian].

Istoriia khvoroby, 1962 - Istoriia khvoroby [Case history]. Perets, 1962, Nr 3, p. 11 [in Ukrainian].

Kaplan, 1960 - Kaplan L. Pohlyan, yakyi krasun stoit...: karykatura [Look at, there is handsome man...: caricature]. Perets, 1960, Nr 23, p. 2 [in Ukrainian].

Kiev, 1985 - Kiev. Entsyklopedicheskii spravochnik / Pod redaktsiei A. V. Kudrytskoho [Kiev. Encyclopedic Guide]. Kiev, 1985. 794 p. [in Russian].

Kombinovanyi brak, 1963 - Kombinovanyi brak [Combined spoilage]. Perets, 1963, Nr 14, p. 3 [in Ukrainian].

Komu viddaty, 1963 - Komu viddaty palmu pershosti? [Who will receive the palm of supremacy?]. Perets, 1963, Nr 3, p. 3 [in Ukrainian].

Lovych, 1962 - Lovych A. Idetsia pro nas... [It's about us...]. Perets, 1962, Nr 23, p. 6 [in Ukrainian].

Mebelnaia promyshlennost, 1954 - Mebelnaia promyshlennost [Furniture industry]. Bolshaia Sovetskaia Entsyklopedia: V 50-ti tomakh. Tom 26. M., 1954, pp. 596-597 [in Russian]. 
Mebelnyi garnitur, 1954 - Mebelnyi garnitur [Furniture set]. Bolshaia Sovetskaia Entsyklopedia: V 50-ti tomakh. Tom 26. M., 1954, p. 597 [in Russian].

Mykhailiuk, 1954 - Mykhailiuk M. Dorohyi Perche! [Dear Perets!]. Perets, 1954, Nr 12, p. 11 [in Ukrainian].

Moliakevych, 1965 - Moliakevych D. Strashna pomsta [Fearful vengeance]. Perets, 1965, Nr 4, p. 9 [in Ukrainian].

Na nohy, 1955 - Na nohy! [On feet!]. Perets, 1955, Nr 7, p. 4 [in Ukrainian].

Navishcho, 1961 - Navishcho shafi nizhky? [Why the wardrobe has legs?]. Perets, 1961, Nr 16, p. 10 [in Ukrainian].

Nakonechnyi, 1935 - Nakonechnyi A. Chy ne mozhesh ty nas prokonsultuvaty?.. [Can you advise us?..]. Perets, 1964, Nr 20, p. 10 [in Ukrainian].

Narodne hospodarstvo, 1935 - Narodne hospodarstvo URSR: Statystychnyi dovidnyk [National Economy of the Ukrainian SSR: Statistic Reference-book]. Kyiv, 1935. 664 p. [in Ukrainian].

Narodnoie khoziaistvo, 1987 - Narodnoie khoziaistvo SSSR za 70 let: Yubileinyi statisticheskii yezhehodnik [National Economy of the USSR for 70 years: Anniversary Statistical Yearbook]. Moscow, 1987. 766 p. [in Russian].

Nastup, 1965 - Nastup luhanskykh lizhkovykiv [The offensive of Lugansk beds producers]. Perets, 1965, Nr 2, p. 2 [in Ukrainian].

Ne vir, 1956 - Ne vir ocham svoim [Do not believe to your eyes]. Perets, 1956, Nr 16, p. 8 [in Ukrainian].

Ne ostanni, 1963 - Ne ostanni novynky... [Not the latest innovations...]. Perets, 1963, Nr 17, p. 2 [in Ukrainian].

Nedarma skazano, 1956 - Nedarma skazano... [For it is said...]. Perets, 1956, Nr 13, p. 10 [in Ukrainian].

Odna noha, 1964 - Odna noha - tut, druha - tam [One leg here is another there]. Perets, 1964, Nr 11, p. 3 [in Ukrainian].

Onyshchuk, 1963 - Onyshchuk K. Namaliuite retsenziiu [Draw a review]. Perets, 1963, Nr 9, p. 3 [in Ukrainian].

Oshukani yuviliary, 1965 - Oshukani yuviliary [The duped heroes of an anniversary]. Perets, 1965, Nr 13, p. 5 [in Ukrainian].

Palamar, 1960 - Palamar Ye. Kupyla ya... [I bought...]. Perets, 1960, Nr 9, p. 8 [in Ukrainian].

Perchanskyi vertoliot, 1960 - Perchanskyi vertoliot [Helicopter of Perets]. Perets, 1960, Nr 19, p. 8 [in Ukrainian].

Plakhotnyk, Bondarenko, 1965 - Plakhotnyk A., Bondarenko B. Khochesh razom z namy povorozhyty?.. [Do you want to tell fortunes with us?..]. Perets, 1965, Nr 20, p. 10 [in Ukrainian].

Pokorobleni korobky, 1960 - Pokorobleni korobky [Warped boxes]. Perets, 1960, Nr 11, p. 2 [in Ukrainian].

Ponomarenko, Riznyk, 2003 - Ponomarenko L., Riznyk O. Kyiv. Korotkyi toponimichnyi dovidnyk [Kyiv. The Short Toponymic Guide]. Kyiv, 2003. 124 p. [in Ukrainian].

Potishni mebli, 1960 - Potishni mebli [Amusing furniture]. Perets, 1960, Nr 10, p. 11 [in Ukrainian].

Prytsker, 1963 - Prytsker M. Umovy brakorobiv [Terms of the bunglers]. Perets, 1963, Nr 21, p. 3 [in Ukrainian].

Prokhorenko, 2010 - Prokhorenko O. Naukovo-pedahohichna intelihentsiia yak sotsialno-profesiynyi prosharok u 1945 - 1955 rr. [Scientific-pedagogical intellectuals as a social-professional stratum in 1945 - 1955]. Povoienna Ukraina: narysy sotsialnoi istorii (druha polovyna 1940-kh - seredyna 1950-kh rr.): U 2-kh knyhakh, 3-kh chastynakh, Knyha. 1, chastyny 1-2. Kyiv, 2010, pp. 177-208 [in Ukrainian].

Robytsia tak, 1959 - Robytsia tak... [It is done so...]. Perets, 1959, Nr 10, p. 10 [in Ukrainian].

Svaliavska novynka, 1965 - Svaliavska novynka [The innovation of Svaliava]. Perets, 1965, Nr 17, p. 10 [in Ukrainian].

Svizhyi brak, 1959 - Svizhyi brak [Fresh spoilage]. Perets, 1959, Nr 10, p. 10 [in Ukrainian].

Svoia «indyvidualnist», 1963 - Svoia «indyvidualnist» [Own individuality]. Perets, 1963, Nr 12, p. 3 [in Ukrainian].

Soloviov, 1960 - Soloviov H. Kolys zabobonni liudy vorozhyly... [Formerly superstitious people told fortunes...]. Perets, 1960, Nr 12, p. 9 [in Ukrainian].

Son i snovydinnia, 1963 - Son i snovydinnia [Sleep and Dreams]. Perets, 1963, Nr 1, p. 2 [in Ukrainian].

Tolkachov, 1954 - Tolkachov Z. A chomu ne sidaty?..: karykatura [And why not allowed sit down?..]. Perets, 1954, Nr 10, p. 7 [in Ukrainian].

U dnipropetrovskykh brakorobiv, 1963 - U dnipropetrovskykh brakorobiv [Visiting the Dnipropetrovsk bunglers]. Perets, 1963, Nr 14, p. 3 [in Ukrainian].

U kyivskykh brakorobiv, 1963 - U kyivskykh brakorobiv [Visiting the Kyiv bunglers]. Perets, 1963, Nr 18, p. 3 [in Ukrainian]. 
Unikalna znakhidka, 1958 - Unikalna znakhidka [Unique find]. Perets, 1958, Nr 13, p. 11 [in Ukrainian].

Fantastyka, 1963 - Fantastyka na stendakh [Fantasy on the stands]. Perets, 1963, Nr 6, p. 2 [in Ukrainian].

Kharchenko, Didenko, 1963 - Kharchenko B., Didenko K. Pro dyvany, kepky i paraleli [About sofas, caps and parallels]. Perets, 1963, Nr 22, p. 3 [in Ukrainian].

Chabanivskyi, 1958 - Chabanivskyi M. Hordiiv vuzol [Gordian knot]. Perets, 1958, Nr 11, pp. 6-7 [in Ukrain$\operatorname{ian}]$.

Chernivetska mebleva fabryka, 1962 - Chernivetska mebleva fabryka vypuskaie u prodazh... [Chernivtsi furniture factory is on sale...]. Perets, 1962, $\mathrm{Nr} 4$, p. 6 [in Ukrainian].

Chomu pryimach plakav, 1960 - Chomu pryimach plakav... [Why was the receiver crying...]. Perets, 1960, Nr 11, p. 2 [in Ukrainian].

Yankovska, 2015 - Yankovska O. Industrializatsiia zhytlovoho budivnytstva [Industrialization of house-building]. Sotsialni transformatsii v Ukraini: piznii stalinizm i khrushchovska doba: Kolektyvna monohrafiia. Kyiv, 2015, pp. 213-231. [in Ukrainian].

Стаття надійила до редакиії 02.02.2018 p. 